\title{
Recovery of coal particles from a tailing dam for environmental protection and economical beneficiations
}

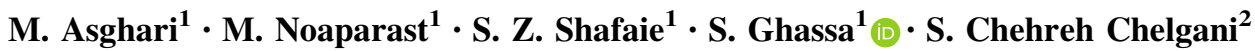

Received: 17 November 2017 /Revised: 11 January 2018/Accepted: 29 January 2018/Published online: 22 February 2018

(C) The Author(s) 2018. This article is an open access publication

\begin{abstract}
Considerable amounts of coal particles are accumulated in the tailing dams of washing plants which can make serious environmental problems. Recovery of these particles from tailings has economically and environmentally several advantages. Maintaining natural resources and reducing discharges to the dams are the most important ones. This study was examined the possibility to recover coal particles from a tailing dam with $56.29 \%$ ash content by using series of processing techniques. For this purpose, gravity separation (jig, shaking table and spiral) and flotation tests were conducted to upgrade products. Based the optimum value of these processing methods, a flowsheet was designed to increase the rate of recovery for a wide range of coal particles. Results indicated that the designed circuit can recover over $90 \%$ of value coal particles and reduce ash content of product to less than $14 \%$. These results can potentially be used for designing an industrial operation as a recycling plant and an appropriate instance for other areas to reduce the environmental issues of coal tailing dams.
\end{abstract}

Keywords Tailing dams $\cdot$ Hazardous issues $\cdot$ Jigging $\cdot$ Shaking table $\cdot$ Spiral $\cdot$ Flotation

\section{Introduction}

During decades, tons of valuable coal particles are accumulated at tailing dams of washing plants due to different problems which were associated by old technologies and complexity of coal processing. On the other hands, demanding growth for high quality coal products from various industries (power plants, cement, paper production and sponge iron units) and decreasing the number of high grade raw coal deposits (Chehreh Chelgani et al. 2011a, b; Royaei et al. 2012; Chehreh Chelgani and Makaremi 2013;

S. Ghassa

sina.ghassa@yahoo.com

$\triangle$ S. Chehreh Chelgani

Saeed.chelgani@gmail.com

1 School of Mining Engineering, University of Tehran, Tehran 16846-13114, Iran

2 Department of Electrical Engineering and Computer Science, University of Michigan, Ann Arbor, MI 48109, USA
Dey et al. 2015; Matin and Chehreh Chelgani 2016) have been complicated coal beneficiation methods and subjected enormous volume of coal particles to wastes (tailing dams). Coal wastes typically can be used in different industries such as building and road making; however, these applications are limited and a huge amount of coal particles are accumulated as dump sand pulps in the tailing dams. These dams can be a source of several environmental and economic problems (Leonhard and Schieder 1990; Valcarce and Canibano 1991; Alonso et al. 1999; Dong et al. 2008).

Various investigations have been explored hazardous issues and environmental impacts of coal tailing piles on air, soil and ground water (Meck et al. 2006; Battioui 2013; Kotsiopoulos and Harrison 2017). They were reported that in some cases acid mine drainage (AMD) of coal tailing dams had a high rate of sulfates, nitrates, chlorides and heavy metals which were above the average that specified by the World Organization of Health (WHO) (Battioui 2013). These AMDs can make serious harmful effects on groundwater quality, river flows and ecology of around 
their deposits (Sengupta 1993; Simate and Ndlovu 2014; Kefeni et al. 2017; Peiravi et al. 2017). Moreover, coneshaped damps of coal tailing can potentially be a source of self-ignition and possible explosion (Siboni et al. 2004; Adiansyah et al. 2017).

Recovery of coal particles from tailing dams by using various processing techniques is a potential method to overcome these problems. Preparation of coal in washing plants employs number of circuits (in parallel) for cleaning operation and each circuit is designed to optimally process a specific size range of coal particles (Cierpisz 2017). Thus, the implementation for recovery of coal particles from tailing dams has to depend on methods which used for coal washing and the size distribution of particles $(\mathrm{Bu}$ et al. 2017). The dissemination of fine ash-forming minerals in the coal structure has a critical challenge in recovery of coal particles from tailing dams. Finding appropriate methods to decrease ash content of coal tailing is essential for upgrading quality of products. Gravity (jigging, tabling or spiral) and flotation separation are typical beneficiation techniques that can be used to recover coal particles (Dey et al. 2013; Taha et al. 2017; Chehreh Chelgani et al. 2018). It was well understood that coal's organic and inorganic (ash) parts have different floatability rate for example hydrophobicity of macerals can decrease in the following order examined Eastern Kentucky coal and arranged the macerals according to decreasing of floatability in order of pseudovitrinite (high $R_{\max }$ ) > pseudovitrinite (low $R_{\max }$ ) > vitrinite (high $\left.R_{\max }\right)>$ vitrinite (low $R_{\max }$ ) = micrinite $=$ exinite $=$ semifusinite $>$ resinite $>$ fusinite (Jorjani et al. 2009; Lin et al. 2017).

Furthermore, the liberation size of particles and a significant difference between the specific gravity (S.G) of coal and their ash minerals are keys for the gravity separation which generally is an environmentally friendly method (Mitchell et al. 1997). However low efficiency of gravity methods can increase the number of separation stages and lead enormous tailing that consists of unrecovered material (Zhao et al. 2013). Coal beneficiation by froth flotation is a well-established processing method to recover fine particles (mainly below $700 \mu \mathrm{m}$ ) (Dey and Bhattacharyya 2007; Dickinson et al. 2015; Jaiswal et al. 2015; Wang et al. 2017). The oil-based reagents are typical collectors to cover oxidized surfaces of coal particles and improve their float-abilities (Polat et al. 1999; Harris and Fuerstenau 2000; Jena et al. 2008; Han et al. 2014; Wen et al. 2017).

Since 2009, Iron productions have shown a considerable growth in Iran which increased the importance of coal reserves in this country. One of the main coal washing plants in the north of Iran that produces coking coal is Anjir-Tangeh (coke as a fuel plays critical characters for the steel-making industry, and approximately there is no substitution for it). In this plant, flotation and jigging are the main processing methods for upgrading coal products. The desired coal feed with $30 \%$ ash content is washing by rock sorting and beneficiated by jig and flotation in a continuous circle, and the waste materials are accumulated in tailing dam. This investigation based on the plant circuit is going to examine various processing methods to recovery value coal particles from high ash content waste materials, subject them for steel making industries and decrease environmental problems for area around AnjirTangeh plant. For these purposes, different gravity and flotation separation tests were used to recover various coal particle sizes from the tailing dam. Results of this study can potentially scale up and use for the optimized manufacturing beneficiation to upgrade coal particles from the tailing dam of Anjir-Tangeh plant and reduce environmental problems of that area.

\section{Materials and methods}

\subsection{Sample preparation}

One ton representative sample was obtained from tailing dam of Anjir-Tangeh (Zirab) coal washing plant. Samples crushed, screened, blended, homogenized and prepared for characterization studies; ash content analysis, specific gravity, X-ray diffraction (XRD) and processing experiments. Table 1 shows the sample size distribution and ash content at different size fractions. The ash content was determined based on ASTM D 3174 and it was $56.29 \%$ in the average for the feed from the tailing dam. The XRD analysis was carried out by a Bruker (Advance D8) X-ray diffract meter. XRD results (Fig. 1) indicated that the coal tailing particles are mainly associated with halloysite as a clay mineral and quartz. The measured specific gravity and bulk density of samples were 1.91 and $1 \mathrm{~g} / \mathrm{cm}^{3}$, respectively.

\subsection{Experimental methods and procedures}

Representative samples were subjected for processing by gravity and flotation separation. For gravity separation, jig, shaking table and spiral were examined. For jig two important process parameters are pulsation frequency and upward water flow. Jigging was performed for three different particle size ranges: $-15+10,-10+5$ and $-5+2 \mathrm{~mm}$. The jig tests were carried out by a Denver (Batac type) laboratory scale with pulsation frequency of 90, 120 and $150 \mathrm{~Hz}$ and upward water flow of 8 and $10 \mathrm{~L} /$ min. Jig tests were performed under following conditions: pulsation amplitude of $4 \mathrm{~mm}$ and feed rate of $2.5 \mathrm{~kg} / \mathrm{min}$.

For shaking table, three main variables are feed water flow rate, wash water flow rate and deck tilt angle. The 
Table 1 Particle size analysis of samples from the tailing dam

\begin{tabular}{lcccc}
\hline Particle size range $(\mathrm{mm})$ & Wt. $(\%)$ retained & Cum. over size $(\%)$ & Cum. under size $(\%)$ & Ash content $(\%)$ \\
\hline+25 & 11.06 & 11.06 & 88.94 & 62.92 \\
$-25+15$ & 9.58 & 20.64 & 79.36 & 51.61 \\
$-15+10$ & 10.82 & 31.46 & 68.54 & 55.89 \\
$-10+5$ & 13.04 & 44.50 & 55.50 & 51.96 \\
$-5+2$ & 8.11 & 52.61 & 47.39 & 62.26 \\
$-2+1$ & 14.08 & 66.69 & 33.31 & 57.53 \\
$-1+0.6$ & 7.23 & 73.92 & 26.08 & 53.94 \\
-0.6 & 26.08 & 100.00 & 0.00 & 55.67 \\
\hline
\end{tabular}

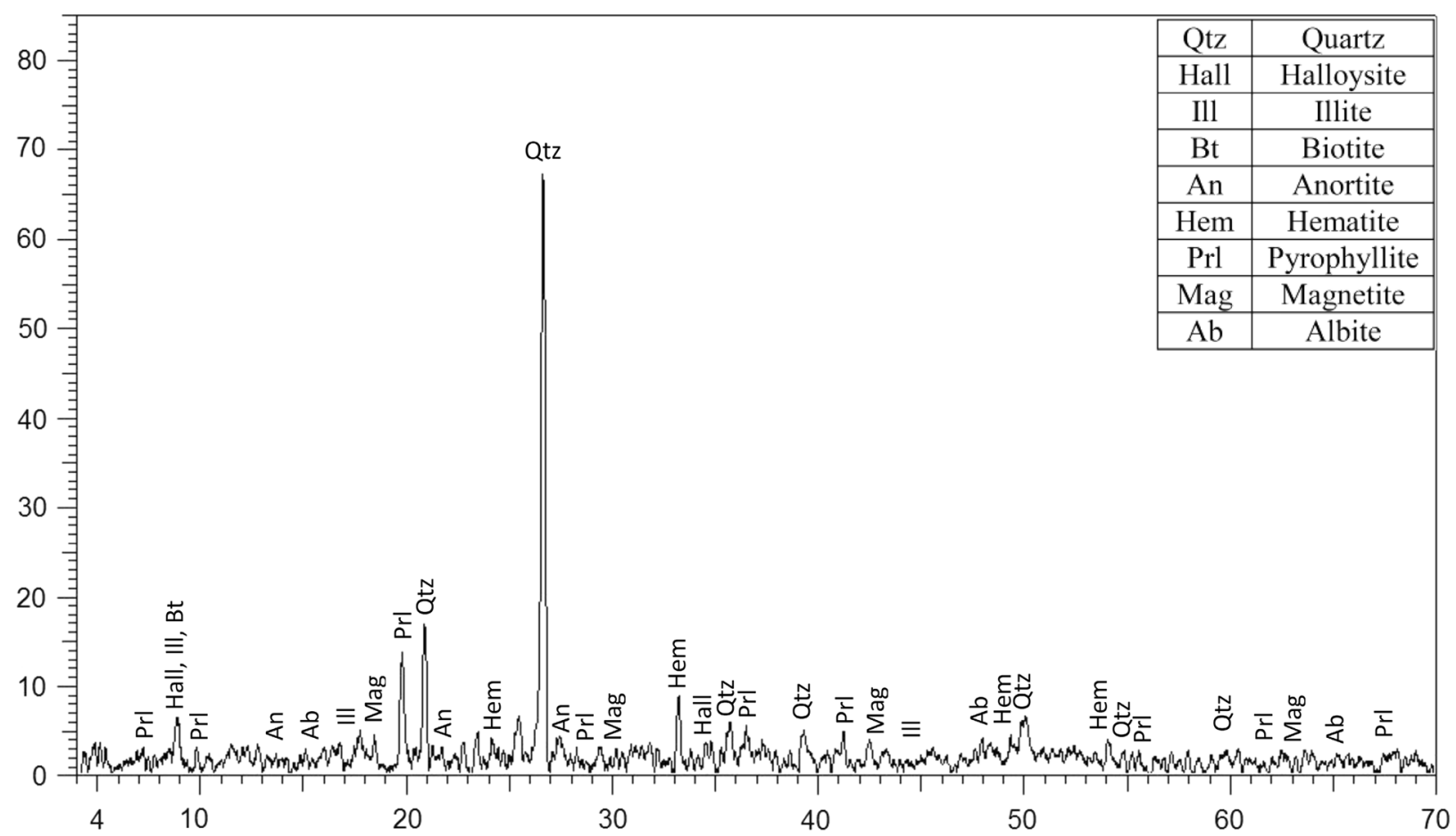

Fig. 1 X-ray diffraction pattern of sample

process was explored in a Denver (Wilfley type) laboratory-scale in three particle size ranges of $-5+2$, $-2+0.150$, and $-1+0.150 \mathrm{~mm}$ (Table 2). Shaking table test was performed under following conditions: shake amplitude $5 \mathrm{~mm}$, shake frequency $180 \mathrm{cycle} / \mathrm{min}$, longitudinal slope 3 degree and feed rate $200 \mathrm{~g} / \mathrm{min}$. Humphrey spiral tests were carried out by Downer EDi-Mineral Technologies (LD7RC model) pilot-scale. Feed rate and pulp density as two most important parameters were examined to find the optimum upgrading points (particle size $-2+0.6 \mathrm{~mm}$ ).

Flotation experiments were performed in a Denver D12 Sub-Aeration laboratory scale for particle size of - $0.600 \mathrm{~mm}$. Gasoline and Kerosene (1500 and $3000 \mathrm{~g} / \mathrm{t}$ ) as typical coal collectors and MIBC and Pine oil (15 and
$40 \mathrm{~g} / \mathrm{t}$ ) as frothers were used for flotation tests. Flotation conditions were: mixing time $1 \mathrm{~min}$, conditioning time $2 \mathrm{~min}$, skimming time $2 \mathrm{~min}$ and $\mathrm{pH} 7$. For each flotation parameter, two different levels were selected (Table 2) and experiments were designed based on the most important variations. Pearson correlation (r) (Leonenko et al. 2013; Zhou et al. 2016) was used to assess interactions among various variables and explore their effects on recovery of coal particles. The variety $r$ is a linear inter-correlation measurement between two variables which ranges from -1 to +1 . The sign of the Pearson shows the direction of the interaction. Typically, $-0.6<r<0.6$ shows that there is a strong interaction between two parameters (Chehreh Chelgani et al. 2011a, b, 2016a, b). 
Table 2 Levels of important variables for various separation methods were used for the experimental design

\begin{tabular}{|c|c|c|c|}
\hline \multicolumn{4}{|l|}{ Jigging } \\
\hline Pulsation frequency $(\mathrm{Hz})$ & 90 & 120 & 150 \\
\hline Size $(\mu \mathrm{m})$ & $-15+10$ & $-10+5$ & $-5+2$ \\
\hline Upward water flow rate $(\mathrm{L} / \mathrm{min})$ & & 8 & 10 \\
\hline \multicolumn{4}{|l|}{ Shaking table } \\
\hline Deck tilt angle $\left(^{\circ}\right)$ & 12 & 14 & 16 \\
\hline Wash water flow rate $(\mathrm{L} / \mathrm{min})$ & 8 & 10 & 12 \\
\hline Feed water flow rate $(\mathrm{L} / \mathrm{min})$ & 8 & 10 & 12 \\
\hline Size distribution $(\mathrm{mm})$ & $-5+2$ & $-2+0.15$ & $-1+0.15$ \\
\hline \multicolumn{4}{|l|}{ Spiral } \\
\hline Solid percentage $(\%)$ & 10 & 20 & 30 \\
\hline Feed rate $(\mathrm{t} / \mathrm{h})$ & 0.8 & 1.7 & 3 \\
\hline \multicolumn{4}{|l|}{ Flotation } \\
\hline Collector-Kerosene (g/t) & & 1500 & 3000 \\
\hline Collector-Gasoline (g/t) & & 1500 & 3000 \\
\hline Frother-MIBC $(\mathrm{g} / \mathrm{t})$ & & 15 & 40 \\
\hline Frother-Pine oil $(\mathrm{g} / \mathrm{t})$ & & 15 & 40 \\
\hline Solid percentage $(\%)$ & & 10 & 20 \\
\hline Impeller speed (rpm) & & 1000 & 1500 \\
\hline
\end{tabular}

\section{Results and discussion}

\subsection{Gravity tests}

\subsubsection{Jig tests}

Fifteen jigging tests (Table 3) were designed based on selected effective variables (Table 2) to find the optimum points of each parameter. Inter-correlation assessment among variables with coal recovery indicated that the pulsation frequency had the highest effect on recovery and by increasing the pulsation, recovery was decreased (Fig. 2a). Results indicated that the highest recovery was provided when pulsation frequency was $90 \mathrm{~Hz}$, upward water flow rate was $8(\mathrm{~L} / \mathrm{min})$ and size fraction $-10+5$. In general, jigging recovery was not significant (below $50 \%)$. This low recovery can be due to the coarse particle size of feed (above $2 \mathrm{~mm}$ ). These results indicated although jigs were designed for the washing of coal in coarser size range, liberation degree (liberation between

Table 3 Jigging tests and their representative results

\begin{tabular}{lcrcrc}
\hline Test no. & Pulsation frequency $(\mathrm{Hz})$ & Upward water flow rate $(\mathrm{L} / \mathrm{min})$ & Size distribution $(\mathrm{mm})$ & Ash content $(\%)$ & Combustible recovery $(\%)$ \\
\hline 1 & 120 & 8 & $-5+2$ & 24.75 & 17.94 \\
2 & 120 & 10 & $-5+2$ & 11.85 & 19.43 \\
3 & 150 & 8 & $-5+2$ & 8.73 & 17.03 \\
4 & 150 & 10 & $-5+2$ & 16.33 & 26.60 \\
5 & 90 & 8 & $-5+2$ & 22.88 & 9.53 \\
6 & 120 & 8 & $-10+5$ & 14 & 48.90 \\
7 & 120 & 10 & $-10+5$ & 13.44 & 29.41 \\
8 & 150 & 8 & $-10+5$ & 10.37 & 38.09 \\
9 & 150 & 10 & $-10+5$ & 15.79 & 39.85 \\
10 & 90 & 8 & $-10+5$ & 10.51 & 49.92 \\
11 & 120 & 8 & $-15+10$ & 6.76 & 22.85 \\
12 & 120 & 10 & $-15+10$ & 10.68 & 28.70 \\
13 & 150 & 8 & $-15+10$ & 15.24 & 9.79 \\
14 & 150 & 10 & $-15+10$ & 7.47 & 17.54 \\
15 & 90 & 8 & $-15+10$ & 7.8 & 23.84
\end{tabular}


combustible parts of coal from ash) play a critical rule and jigging can be considered as a pretreatment method.

\subsubsection{Shaking table tests}

Based on selected levels (Table 2) for effective variables (the transverse slope, feed water flow rate, size fraction and wash water flow rate) thirty six shaking table tests were designed (Table 4). Outputs indicated that there is a positive inter-correlation between size distribution and recovery $(r \sim 0.16) \quad$ (Fig. 2b). The highest size fraction $(-5+2 \mathrm{~mm})$ showed the better performance in the shaking table tests could be explain by the fact that the device is not appropriately functional for the small size ranges. The results also showed that an increase in the deck tilt angle cause a decrease in concentrate grade and an increase in valuable particle recovery. On the other hand, water flow rate has a direct relation with concentrate grade. By increasing the water flow rate gangue materials crawl more along the table and transport to the tailing part and ash content will decrease (Meloy et al. 1994; Zhao et al. 2013).

The highest recovery can observe when deck tilt angle was $12^{\circ}$, feed water flow rate and wash water flow rate were $12(\mathrm{~L} / \mathrm{min})$ (Table 4). Therefore, the following points were selected as the optimal values: deck tilt angle $12^{\circ}$, feed water flow rate and wash water flow rate $12(\mathrm{~L} / \mathrm{min})$ and size fraction $-5+2 \mathrm{~mm}$.

\subsubsection{Spiral tests}

Two levels for effective parameters (pulp density and feed rate) and one center point with two times repeating (six runs) were performed for spiral tests (Table 5). Based on these results (Fig. 2c), both solid percentage and feed rate have positive relationship with recovery. The material velocity and centrifugal force in spiral will increase by increasing the feed rate and solid percentage which lead to an increase in coal particle recovery. These results could be due to the effect of particle size classification in the flowing films where spirals tend to have a high S.G cut point (1.7-2.1); therefore, misplace high amounts of high ash fines into the clean coal. The following values were selected as the optimal points: solid percentage $30 \%$ and feed rate $1.7(\mathrm{t} / \mathrm{h})$ which could recover over $70 \%$ of value materials.

\subsection{Flotation tests}

Based on considered levels for flotation variables (Table 2), sixteen different tests were designed. Inter- a

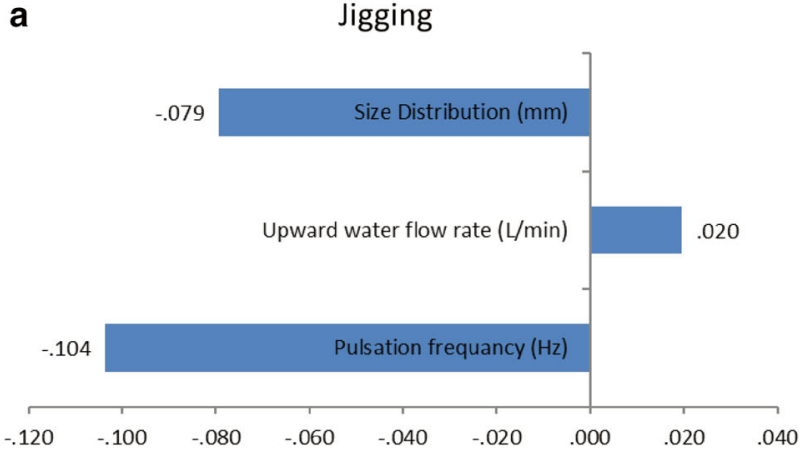

C

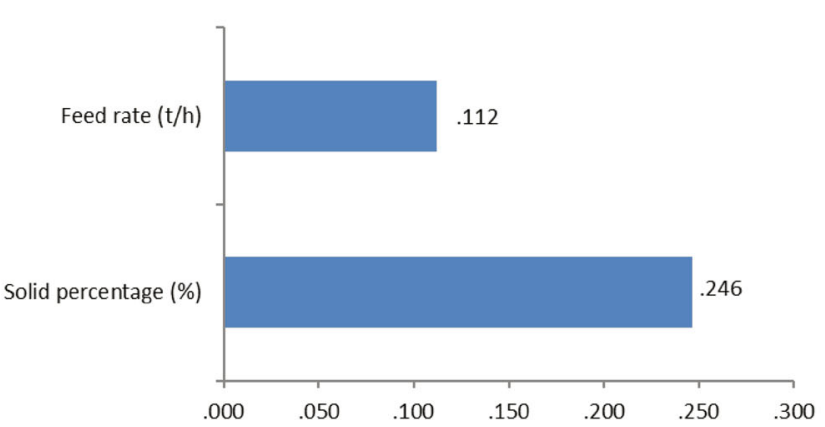

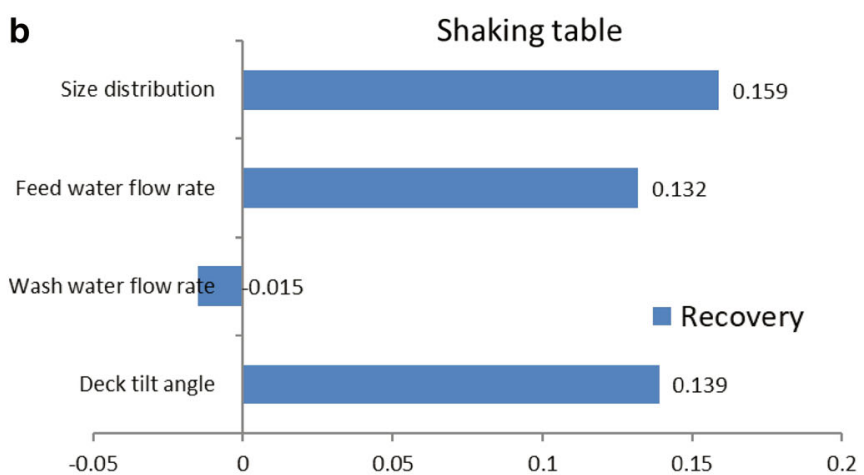

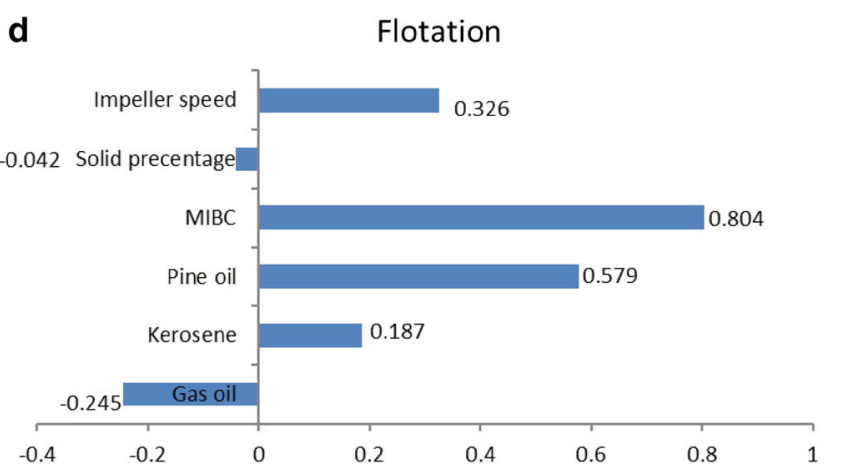

Fig. 2 Pearson correlation assessment between various conditions and their representative 
Table 4 Shaking table tests and their representative results

\begin{tabular}{|c|c|c|c|c|c|c|}
\hline Test no. & Deck tilt angle $\left(^{\circ}\right)$ & $\begin{array}{l}\text { Wash water flow } \\
\text { rate }(\mathrm{L} / \mathrm{min})\end{array}$ & $\begin{array}{l}\text { Feed water flow } \\
\text { rate }(\mathrm{L} / \mathrm{min})\end{array}$ & $\begin{array}{l}\text { Size distribution } \\
(\mathrm{mm})\end{array}$ & $\begin{array}{l}\text { Concentrate ash } \\
\text { content }(\%)\end{array}$ & $\begin{array}{l}\text { Combustible } \\
\text { recovery }(\%)\end{array}$ \\
\hline 1 & 12 & 8 & 8 & $-5+2$ & 21.36 & 53.17 \\
\hline 2 & 12 & 8 & 12 & $-5+2$ & 19.45 & 49.77 \\
\hline 3 & 12 & 12 & 8 & $-5+2$ & 20.81 & 15.05 \\
\hline 4 & 12 & 12 & 12 & $-5+2$ & 13.84 & 55.77 \\
\hline 5 & 16 & 8 & 8 & $-5+2$ & 23.73 & 39.33 \\
\hline 6 & 16 & 8 & 12 & $-5+2$ & 25.62 & 47.06 \\
\hline 7 & 16 & 12 & 8 & $-5+2$ & 29.98 & 35.16 \\
\hline 8 & 16 & 12 & 12 & $-5+2$ & 20.6 & 33.92 \\
\hline 9 & 14 & 10 & 10 & $-5+2$ & 18.18 & 26.77 \\
\hline 10 & 14 & 10 & 10 & $-5+2$ & 16.52 & 31.27 \\
\hline 11 & 14 & 10 & 10 & $-5+2$ & 17.77 & 24.21 \\
\hline 12 & 14 & 10 & 10 & $-5+2$ & 18.42 & 35.72 \\
\hline 13 & 12 & 8 & 8 & $-2+0.15$ & 52.22 & 4.44 \\
\hline 14 & 12 & 8 & 12 & $-2+0.15$ & 51.94 & 20.94 \\
\hline 15 & 12 & 12 & 8 & $-2+0.15$ & 49.24 & 9.26 \\
\hline 16 & 12 & 12 & 12 & $-2+0.15$ & 45.88 & 14.64 \\
\hline 17 & 16 & 8 & 8 & $-2+0.15$ & 39.66 & 25.87 \\
\hline 18 & 16 & 8 & 12 & $-2+0.15$ & 39.16 & 26.24 \\
\hline 19 & 16 & 12 & 8 & $-2+0.15$ & 37.85 & 47.59 \\
\hline 20 & 16 & 12 & 12 & $-2+0.15$ & 36 & 42.36 \\
\hline 21 & 14 & 10 & 10 & $-2+0.15$ & 42.77 & 16.99 \\
\hline 22 & 14 & 10 & 10 & $-2+0.15$ & 46.7 & 12.96 \\
\hline 23 & 14 & 10 & 10 & $-2+0.15$ & 45.1 & 10.11 \\
\hline 24 & 14 & 10 & 10 & $-2+0.15$ & 47.14 & 11.42 \\
\hline 25 & 12 & 8 & 8 & $-1+0.15$ & 39.07 & 43.58 \\
\hline 26 & 12 & 8 & 12 & $-1+0.15$ & 45.35 & 27.02 \\
\hline 27 & 12 & 12 & 8 & $-1+0.15$ & 41.32 & 44.96 \\
\hline 28 & 12 & 12 & 12 & $-1+0.15$ & 40.76 & 52.54 \\
\hline 29 & 16 & 8 & 8 & $-1+0.15$ & 40.54 & 38.47 \\
\hline 30 & 16 & 8 & 12 & $-1+0.15$ & 39.54 & 46.18 \\
\hline 31 & 16 & 12 & 8 & $-1+0.15$ & 40.61 & 35.79 \\
\hline 32 & 16 & 12 & 12 & $-1+0.15$ & 40.67 & 29 \\
\hline 33 & 14 & 10 & 10 & $-1+0.15$ & 43.62 & 27.36 \\
\hline 34 & 14 & 10 & 10 & $-1+0.15$ & 18.41 & 31.36 \\
\hline 35 & 14 & 10 & 10 & $-1+0.15$ & 41.28 & 38 \\
\hline 36 & 14 & 10 & 10 & $-1+0.15$ & 42.56 & 32.39 \\
\hline
\end{tabular}

correlation results indicated that increasing the concentration of gasoline can decrease the recovery while there is a positive correlation between kerosene and recovery (Fig. 2d). Moreover, outputs illustrated that there is a positive relationship between recovery and concentration of frothers and increasing their concentrations could improve the recovery (Fig. 2d). Increasing the frother concentration causes to produce stable bubbles with lower diameter and more surface area. This phenomenon increases the froth transfer capacity and consequently raise the recovery (Azizi et al. 2014; Li et al. 2016).

Based on the experiment results (Table 6), the following values were provided the highest recovery: collector kerosene $3000 \mathrm{~g} / \mathrm{t}$, frother pine oil $40 \mathrm{~g} / \mathrm{t}$, solid percentage $10 \%$ and impeller speed $1000 \mathrm{rpm}$. A comparison between recoveries of gravity and flotation separation indicated that flotation could provide the highest recovery (90\%) among other beneficiation methods (apart from size fractions) 
Table 5 Spiral tests and their representative results

\begin{tabular}{llll}
\hline Solid percentage $(\%)$ & Feed rate $(\mathrm{t} / \mathrm{h})$ & Combustible recovery $(\%)$ & Concentrate ash $(\%)$ \\
\hline 10 & 3 & 65.07 & 16.89 \\
10 & 0.8 & 70.56 & 20.95 \\
30 & 1.7 & 71.5 & 27.76 \\
30 & 3 & 68.71 & 17.63 \\
20 & 0.8 & 60.75 & 13.97 \\
20 & 1.7 & 64.15 & 17.29 \\
\hline
\end{tabular}

Table 6 Flotation tests and their representative results

\begin{tabular}{|c|c|c|c|c|c|c|c|c|}
\hline Test no. & Type collector & $\begin{array}{l}\text { Collector } \\
\text { dosage }(\mathrm{g} / \mathrm{t})\end{array}$ & Frother type & $\begin{array}{l}\text { Frother } \\
\text { dosage }(\mathrm{g} / \mathrm{t})\end{array}$ & $\begin{array}{l}\text { Solid } \\
\text { percentage }(\%)\end{array}$ & $\begin{array}{l}\text { Impeller } \\
\text { speed (rpm) }\end{array}$ & $\begin{array}{l}\text { Ash content }(\%) \\
\text { Concentrate tailing }\end{array}$ & $\begin{array}{l}\text { Combustible } \\
\text { recovery }(\%)\end{array}$ \\
\hline 1 & Kerosene & 1500 & MIBC & 15 & 10 & 1000 & $\begin{array}{l}24 \\
70.5\end{array}$ & 55.93 \\
\hline 2 & Gas oil & 1500 & Pine oil & 40 & 10 & 1000 & $\begin{array}{l}30 \\
79.23\end{array}$ & 76.47 \\
\hline 3 & Kerosene & 3000 & Pine oil & 15 & 10 & 1000 & $\begin{array}{l}28.17 \\
73.24\end{array}$ & 63.74 \\
\hline 4 & Gas oil & 3000 & MIBC & 40 & 10 & 1000 & $\begin{array}{l}29.05 \\
75.56\end{array}$ & 67.31 \\
\hline 5 & Gas oil & 1500 & Pine oil & 15 & 10 & 1500 & $\begin{array}{l}35.31 \\
83.36\end{array}$ & 84.50 \\
\hline 6 & Kerosene & 1500 & MIBC & 40 & 10 & 1500 & $\begin{array}{l}37.85 \\
80.29\end{array}$ & 80.80 \\
\hline 7 & Gas oil & 3000 & MIBC & 15 & 10 & 1500 & $\begin{array}{l}32.88 \\
63.1\end{array}$ & 41.20 \\
\hline 8 & Kerosene & 3000 & Pine oil & 40 & 10 & 1500 & $\begin{array}{l}38.74 \\
87.05\end{array}$ & 90.44 \\
\hline 9 & Gas oil & 1500 & MIBC & 15 & 20 & 1000 & $\begin{array}{l}33.74 \\
66.84\end{array}$ & 48.57 \\
\hline 10 & Kerosene & 1500 & Pine oil & 40 & 20 & 1000 & $\begin{array}{l}33.24 \\
76\end{array}$ & 73.42 \\
\hline 11 & Gas oil & 3000 & Pine oil & 15 & 20 & 1000 & $\begin{array}{l}31.16 \\
74.17\end{array}$ & 68.19 \\
\hline 12 & Kerosene & 3000 & MIBC & 40 & 20 & 1000 & $\begin{array}{l}27.34 \\
75.24\end{array}$ & 68.81 \\
\hline 13 & Kerosene & 1500 & Pine oil & 15 & 20 & 1500 & $\begin{array}{l}33.03 \\
71.09\end{array}$ & 63.75 \\
\hline 14 & Gas oil & 3000 & Pine oil & 40 & 20 & 1500 & $\begin{array}{l}33.78 \\
82.49\end{array}$ & 83.06 \\
\hline 15 & Gas oil & 1500 & MIBC & 40 & 20 & 1500 & $\begin{array}{l}35.96 \\
79.18\end{array}$ & 79.66 \\
\hline 16 & Kerosene & 3000 & MIBC & 15 & 20 & 1500 & $\begin{array}{l}30.82 \\
72.95\end{array}$ & 66.18 \\
\hline
\end{tabular}

(Fig. 3). However, based on the gravity separation results it can be seen that froth flotation was inefficient in the rejection of pyrite and so a combination of gravity and flotation techniques can consider to increase ash removal and produce clean products. 


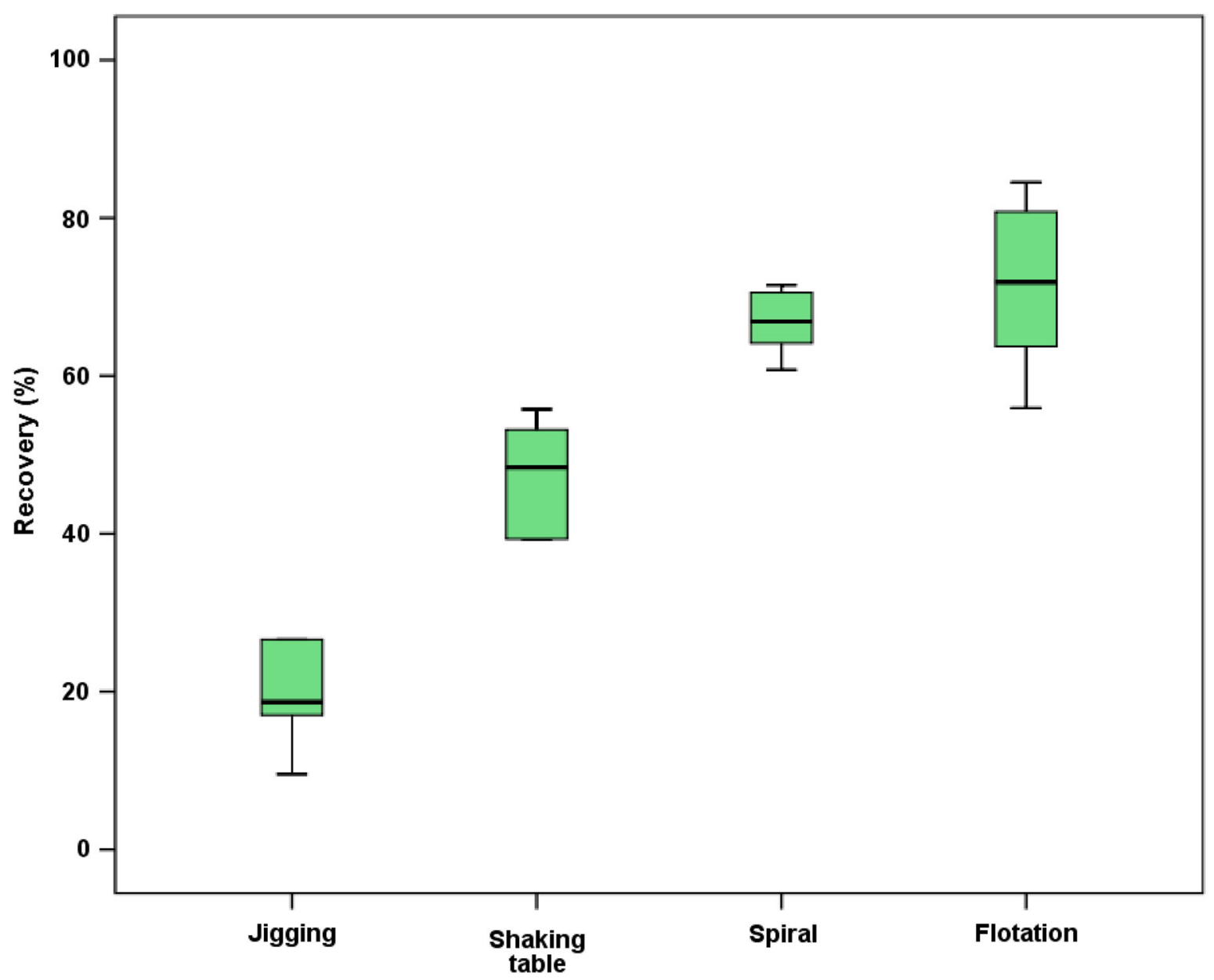

Fig. 3 A comparison among provided coal recoveries of various separation techniques

\subsection{Presented process flowsheet based on the test results}

Performing of the above tests to find the optimum condition is essential to determine the arrangement of equipment in a circle (flowsheet). Based on the above results, gravity methods (such as jig, shaking table and spiral) for coarse particles and flotation for fine particles can consider for increasing the cumulative recovery. Figure 4 presents the appropriate flowsheet for recovery of coal particles from Anjir-Tangeh (Zirab) coal tailing dam. In this circuit, the tailing at first coal subjected to the double deck vibrating screen with mesh size of $-15+5 \mathrm{~mm}$. The screen oversize $(+15 \mathrm{~mm})$ would be returned to the crushing unit for size reduction. The particles with size of $-15+5 \mathrm{~mm}$ feed to the jig machine. The particles with size of $-5+2 \mathrm{~mm}$ would transfer to the shaking table to be enriched. In this case, the obtained middle product that has high ash content will be considered as waste materials. The spiral method was used for particles size of $-2+0.6 \mathrm{~mm}$. Furthermore, the spiral middle product would consider as waste materials (because they have high ash content). Finally fine coal particles with size distribution of $-0.6 \mathrm{~mm}$ will be processed by flotation machines. Testing the designed flowsheet indicated that the ash content for jig, shaking table and spiral concentrate were $14.5 \%(7.35$ wt.\%), $13.84 \%$ (2 wt.\%) and $13.97 \%$ (7.53 wt.\%). The flotation concentrate, after one stage rougher and two stages cleaners, had ash content of $14.22 \%$ (4.7 wt.\%). Therefore, the final concentrate could have cumulative ash content of $14.19 \%(21.58 \mathrm{wt} \%)$. In other words, the process can recover over $90 \%$ of value coal particles and reduce ash content to less than $14 \%$.

\section{Conclusions}

A huge amount of coal particles in the tailing dams (accumulated as dump sand pulps) can be a source of several environmental problems. In this investigation different gravity (jigging, tabling and spiral) and flotation separation experiments were performed to recover coal particles from 


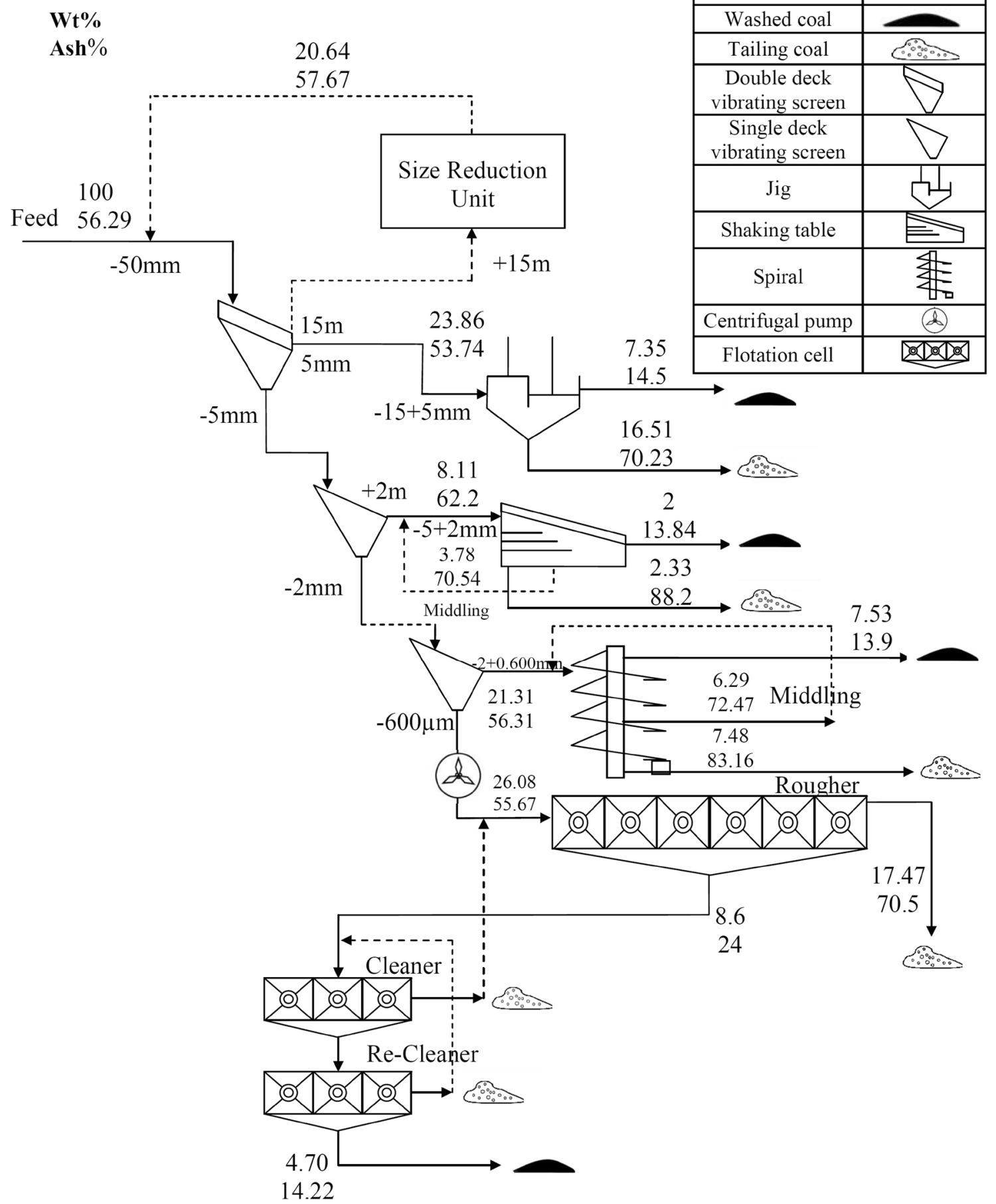

Fig. 4 The appropriate flowsheet for recovery of coal particles from coal tailing dam

the tailing dam of Anjir-Tangeh plant, reduce environmental problems and used recovered particles in steel making industries. Various experiments indicated that optimum conditions to recover coal by different methods are: Jigging; pulsation frequency was $90 \mathrm{~Hz}$, upward water flow rate was $8(\mathrm{~L} / \mathrm{min})$ and size fraction $-10+5$, tabling: deck tilt angle $12^{\circ}$, feed water flow rate and wash water flow rate $12(\mathrm{~L} / \mathrm{min})$ and size fraction $-5+2 \mathrm{~mm}$, spiral: solid percentage $30 \%$ and feed rate $1.7(\mathrm{t} / \mathrm{h})$ and flotation: collector kerosene $3000 \mathrm{~g} / \mathrm{t}$, frother pine oil $40 \mathrm{~g} /$ $\mathrm{t}$, solid percentage $10 \%$ and impeller speed $1000 \mathrm{rpm}$. Based on the optimum conditions, a flowsheet was 
designed. The results of running the flowsheet indicated that the circuit can recover over $90 \%$ of value coal particles and reduce ash content to less than $14 \%$. These results can potentially be used for the scale up and design a recycling plant.

Open Access This article is distributed under the terms of the Creative Commons Attribution 4.0 International License (http://crea tivecommons.org/licenses/by/4.0/), which permits unrestricted use, distribution, and reproduction in any medium, provided you give appropriate credit to the original author(s) and the source, provide a link to the Creative Commons license, and indicate if changes were made.

\section{References}

Adiansyah JS, Haque N, Rosano M, Biswas W (2017) Application of a life cycle assessment to compare environmental performance in coal mine tailings management. $\mathrm{J}$ Environ Manage 199:181-191

Alonso MI, Valdes AF, Martinez-Tarazona RM, Garcia AB (1999) Coal recovery from coal fines cleaning wastes by agglomeration with vegetable oils: effects of oil type and concentration. Fuel 78:753-759

Azizi D, Gharabaghi M, Saeedi N (2014) Optimization of the coal flotation procedure using the Plackett-Burman design methodology and kinetic analysis. Fuel Process Technol 128:111-118

Battioui M (2013) Impact of mining wastes on groundwater quality in the province Jerada. Int J Eng Sci Technol 8:1601-1615

Bu X, Ni C, Xie G, Peng Y, Ge L, Sha J (2017) Preliminary study on foreign slime for the gravity separation of coarse coal particles in a teeter bed separator. Int J Miner Process 160:76-80

Chehreh Chelgani S, Makaremi S (2013) Explaining the relationship between common coal analyses and Afghan coal parameters using statistical modeling methods. Fuel Process Technol 110:79-85

Chehreh Chelgani S, Hart B, Grady WC, Hower JC (2011a) Study relationship between inorganic and organic coal analysis with gross calorific value by multiple regression and ANFIS. Int $\mathbf{J}$ Coal Prep Util 31(1):9-19

Chehreh Chelgani S, Dehghan F, Hower JC (2011b) Estimation of some coal parameters depending on petrographic and inorganic analyses by using Genetic algorithm and adaptive neuro-fuzzy inference systems. Energy Explor Exploit 29(4):479-494

Chehreh Chelgani S, Matin SS, Hower JC (2016a) Explaining relationships between coke quality index and coal properties by random forest method. Fuel 182:754-760

Chehreh Chelgani S, Matin SS, Makaremi S (2016b) Modeling of free swelling index based on variable importance measurements of parent coal properties by random forest method. Measurement 94:416-422

Chehreh Chelgani S, Shahbazi B, Hadavandi E (2018) Support vector regression modeling of coal flotation based on variable importance measurements by mutual information method. Measurement 114:102-108

Cierpisz S (2017) Strategies for control of parallel gravitational coal separation processes. Int J Miner Process 168:68-75

Dey S, Bhattacharyya KK (2007) Split and collectorless flotation to medium coking coal fines for multi-product zero waste concept. Fuel Process 88:585-590

Dey S, Paul GM, Pani S (2013) Flotation behavior of weathered coal in mechanical and column flotation cell. Powder Technol 246:689-694
Dey S, Gangadhar BB, Gopalkrishna SJ (2015) Amenability to dry processing of high ash thermal coal using a pneumatic table. Int $\mathbf{J}$ Min Sci Technol 25:955-961

Dickinson JE, Jiang K, Galvin KP (2015) Fast flotation of coal at low pulp density using the Reflux Flotation Cell. Chem Eng Res Des 101:74-81

Dong KJ, Guo BY, Chu KW, Yu AB, Brake I (2008) Simulation of liquid-solid flow in a coal distributor. Miner Eng 21:789-796

Han OH, Kim MK, Kim BG, Subasinghe N (2014) Chul-Hyun Park, Fine coal beneficiation by column flotation. Fuel Process Technol 126:49-59

Harris GH, Fuerstenau DW (2000) An improved class of universal collectors for the flotation of oxidized and/or low-rank coal. Int J Miner Process 58:99-118

Jaiswal S, Tripathy SK, Banerjee PK (2015) An overview of reverse flotation process for coal. Int J Miner Process 134:97-110

Jena MS, Biswal SK, Rudramuniyappa MV (2008) Study on flotation characteristics of oxidized indian high ash sub-bituminous coal. Miner Process 87:42-50

Jorjani E, Poorali HA, Sam A, Chehreh Chelgani S, Mesroghli S (2009) Prediction of coal response to froth flotation based on coal analysis using regression and artificial neural network. Miner Eng 22(11):970-976

Kefeni KK, Msagati T, Mamba BB (2017) Acid mine drainage: prevention, treatment options, and resource recovery: a review. J Clean Prod 151:475-493

Kotsiopoulos A, Harrison STL (2017) Application of fine desulfurised coal tailings as neutralising barriers in the prevention of acid rock drainage. Hydrometallurgy 168:159-166

Leonenko NN, Meerschaert MM, Sikorskii A (2013) Correlation structure of fractional Pearson diffusions. Comput Math Appl 66:737-745

Leonhard J, Schieder Th (1990) Utilization of washery waste as secondary raw materials in civil engineering and other industries. Aufbereitungstechnik 31:89-97

Li C, Runge K, Shi F, Farrokhpay S (2016) Effect of flotation froth properties on froth rheology. Powder Technol 294:55-65

Lin X, Luo M, Li S, Yang Y, Chen X, Tian B, Wang Y (2017) The evolutionary route of coal matrix during integrated cascade pyrolysis of a typical low-rank coal. Appl Energy 199:335-346

Matin SS, Chehreh Chelgani S (2016) Estimation of coal gross calorific value based on various analyses by random forest method. Fuel 177:274-278

Meck M, Love D, Mapani B (2006) Zimbabwean mine dumps and their impacts on river water quality - a reconnaissance study. Phys Chem Earth 31:797-803

Meloy TP, Williams MC, Bevilacqua P, Ferrara G (1994) Shaking tables-effects of riffles, minerals and metallurgical processing (part A). SME Trans 296:1870-1877

Mitchell CJ, Styles MT, Evans EJ (1997) The design, construction and testing of a simple shaking table for gold recovery: laboratory testing and field trials. Nottingham, British Geological Survey

Peiravi M, Mote SR, Mohanty MK, Liu J (2017) Bioelectrochemical treatment of acid mine drainage (AMD) from an abandoned coal mine under aerobic condition. J Hazard Mater 333:329-338

Polat H, Polat M, Chander S (1999) Kinetics of oil dispersion in the absence and presence of block copolymers. AIChE J 45:1866-1874

Royaei MM, Jorjani E, Chehreh Chelgani S (2012) Combination of microwave and ultrasonic irradiations as a pretreatment method to produce ultraclean coal. Int J Coal Prep Util 32(3):143-155

Sengupta M (1993) Environmental impacts of mining-monitoring, restoration and control. Lewis, London, pp 1-31

Siboni N, Fine M, Bresler V, Loya Y (2004) Coastal coal pollution increases $\mathrm{Cd}$ concentrations in the predatory gastropod Hexaplex 
trunculus and is detrimental to its health. Mar Pollut Bull 49:111-118

Simate GS, Ndlovu S (2014) Acid mine drainage: challenges and opportunities. J Environ Chem Eng 2:1785-1803

Taha Y, Benzaazoua M, Hakkou R, Mansori M (2017) Coal mine wastes recycling for coal recovery and eco-friendly bricks production. Miner Eng 107:123-138

Valcarce FJA, Canibano GJ (1991) Utilizacion de los esterilesdel carbon, vol 1. Jornada Tecnica. E.T.S.I.M, Oviedo, pp 1-22

Wang J, Wang L, Hanotu J, Zimmerman WB (2017) Improving the performance of coal flotation using oscillatory air supply. Fuel Process Technol 165:131-137
Wen B, Xia W, Sokolovic JM (2017) Recent advances in effective collectors for enhancing the flotation of low rank/oxidized coals. Powder Technol 319:1-11

Zhao Y, Zhang Y, Bao S, Liu T, Jiang M (2013) Separation factor of shaking table for vanadium pre-concentration from stone coal. Sep Purif Technol 115:92-99

Zhou H, Deng Z, Xia Y, Fu M (2016) A new sampling method in particle filter based on Pearson correlation coefficient. Neurocomputing 216:208-215 